\title{
Handling Ophelia: A Story in Four Unscripted Scenes ${ }^{1}$
}

Nicoleta Cinpoeş

University of Worcester

\section{Abstract}

Looking at several European productions of Hamlet between 2001 and 2014, this article examines the stage struggle to 'recuperate' an Ophelia that both discursive criticism and visual objectification bury prematurely - albeit by different means and for different aims when claiming, in Laertes’s words: 'The woman will be out' (IV.7.189). ${ }^{1}$ Taking Laertes's words to mean both taking the woman out and putting the woman on view, I will offer a preliminary survey of the customary textual cuts and their effect on Ophelia's part, explore 'the four unscripted scenes’ three European directors: Vlad Mugur, Radu Alexandru Nica, and Jan Klata, have built into their respective productions of the play, and interrogate their overall impact on interpreting Ophelia's part, agency and story within Shakespeare's Hamlet. Nicoleta Cinpoeş is Principal Lecturer at the University of Worcester, UK. Author of Shakespeare's Hamlet in Romania 1778-2008 (Mellen, 2010), editor of and contributor to Doing Kyd (MUP, 2016), she has also published articles in the Shakespeare Bulletin, SEDERI, Testi e linguaggi, Arrêts sur scène, Theatrical Blends and Studia Dramatica.

Key terms: Ophelia, Hamlet, Vlad Mugur, Radu Alexandru Nica, Jan Klata

Like most of my projects, this began in the theatre house, while being a spectator - not to Hamlet but - to Romeo and Juliet. At the end of the play, gathered around the dead bodies of the star-crossed lovers, the rival families do more than 'give hands'; they promise a 'living monument' to their children (5.3.299-304). Similarly, at the end of the funeral scene in Hamlet, king Claudius promises that Ophelia's 'grave shall have a living monument' (V.1.293). Most stage productions of Romeo and Juliet don't black out until some kind of monument to the memory of the dead lovers has been raised. Conversely, all productions of Hamlet dump Ophelia (her body, her story and the promise of a monument to her) and return to the tragedy of the Danish Prince.

\footnotetext{
1 The present article has seen changes and updates following acceptance for publication in the New Theatre Quarterly. For an updated version complete with illustrations, please refer to the published article in the New Theatre Quarterly 32.4 (2016): 307-317. DOI: https://doi.org/10.1017/S0266464X16000397. Published online: 14 October 2016.
} 
In her 'living monument' to reel Ophelias, Carol Chillington Rutter argues that 'Ophelia's role simply vanishes when her body is snatched, and that is bad news [...] not just for her but for Hamlet too'. ${ }^{2}$ I'd like to argue that the business of disputing Ophelia usually starts from the character's uneven presence in the play and the discrepancy between Ophelia-the-text and Ophelia-the-body. Along with this material comes a whole history of 'snatch'-ing, refashioning, and handling Ophelia for projects that range from historicism to feminisms, textual imperialism to performance studies, early modern conduct manuals to contemporary teenage behavioural disorder studies, French impressionist painting to German expressionist poetry, cinema to pornography, Goth iconography and Manga Shakespeare to music, fashion brand, ${ }^{3}$ computer game industry, and recently, and most unfortunately, beverages such as 'Fonte Ophelia' - an Italian brand of still water sold in France or 'Ophelia - Fine Colorado Ale from Breckenridge Brewery' sold in the USA. ${ }^{4}$

If in her book Enter the body, Rutter's project was 'to discover what narrative is silenced in [3] filmtexts, and to what cultural aim, ${ }^{5}$, my pursuit of three European stage productions of Hamlet: Vlad Mugur's for the Cluj National Theatre, Romania (2001), Radu Alexandru Nica's for Sibiu Theatre, Romania (2008), and Jan Klata's for Bochum Theatre, Germany (2013), which I saw at the Gdansk Shakespeare Festival, Poland (2014), focuses on how Ophelia is repeatedly 'put out there' - exhibited?, sold? in another snatching game - and recruited, choreographically into a range of projects, and in doing so sets out to explore the 'narrative(s)' anatomised in these stage productions.

\section{Handling the text}

In the Tragedy of Hamlet, Prince of Denmark, Ophelia appears in 6 out of the play's 20 scenes and she speaks, in 5 of these 6 in a total of 168 lines. ${ }^{6}$ When at home, Ophelia is mostly spoken to; her first self-initiated speech (in II.1) is as much prompted by Hamlet's 'piteous' (II.1.82) state as it is by her father's 'command' to 'repel his letters and den[y]/ hi[m] access’ (II.1.107-9). Ophelia’s only soliloquy (III.1.151-62) is mostly about Hamlet; she 'enters distracted' to deliver her longest self-initiated input: 'a document in madness' (IV.5.179) totalling 74 lines. But even in Shakespeare’s playscript, Ophelia’s 'presence' amounts to (let alone does and means) much more, whether through the ghosting 'the corpse of Ophelia' performs when it enters (never to exit!) after V.1.213, or the ongoing ghosting she performs that rivals the Ghost of King Hamlet's own project in The Tragedy of Hamlet, Prince of Denmark. She is "presenced" when spoken about: as 'sister' by Laertes and 
'daughter' by Polonius in II.2; as 'fair nymph’ by Hamlet in III.1; in IV.5, she is "presenced” first as 'importunate, indeed distract' (2), 'her speech [...] nothing' (7) by a Gentleman, and later as a 'rose of May!' by Laertes, who continues to call her 'Dear maid, kind sister, sweet Ophelia!' (159-60) even when Ophelia's very presence tells otherwise; she is presenced in IV.7 as ‘drowned’ (164), 'mermaid-like’ (176), and 'poor wretch’ (182) by Gertrude, and finally as "grave matter" in the lively debate between the Clowns at the beginning of V.1 and later by Hamlet. This is the rich and conflicting script material available to every stage production of the play.

As with all scripted parts for the stage, Ophelia's is subject to cuts and additions that prioritise directorial (rather than actorly) projects, and such negotiations can be poles apart. In Richard Schechner's environmental Hamlet: That is the Question (Shanghai Theatre Academy, 2007, which I saw at the International Shakespeare Festival, Craiova, 2010), Ophelia was more involved in the plot. She doubled as Marcellus on the battlements, "got mad" when she discovered Polonius's dead body and "went mad" when she lost Hamlet not only over the murder of her father but over his relationship with Horatio, whose eroticism was extensively explored in this production. In Elizabeth LeCompte's Wooster Group's Hamlet (2007, which I saw at the Gdansk Shakespeare Festival in 2012), on the other hand, the choice to double Ophelia with Gertrude (a directorial decision rather than a cue from Richard Burton's 1964 film, which the production emulated and erased throughout) made it necessary to "cut the Ophelia business" - a line scripted in for Hamlet to instruct the computer board team every night. As a consequence, Ophelia was erased in this production from every scene in which both Gertrude and herself should have shared the stage.

In the three productions that make the focus of this article, the overall textual cuts were drastic in order to meet a performance time of 2.10-3.10 hours. While, statistically, Ophelia's part is affected no more than the others', four scenes are commonly up for negotiation. While two of these usually get streamlined, namely Ophelia's only soliloquy (III.1) and the Gentleman's description of Ophelia before her first mad scene (IV.7), the other two, namely Hamlet's visit to Ophelia's closet (II.1) and her drowning (IV.7), despite both being reported events - one by Ophelia herself, the other by Gertrude - end up being performed on stage. Two aspects are of interest in this sense and will make the focus of the present article. Firstly, when cutting the Gentleman's description in IV.7, productions trade off the (Gentleman's) concern that Ophelia's state is a threat to the body politic for the shock effect Ophelia's 
entrance as "distracted" has on the characters present on the stage and the audience alike, and in the process also eliminate the complex issue of articulating and interpreting "mad" Ophelia. ${ }^{7}$ Secondly, it provides theatre productions that choose to stage Ophelia's closet scene and her drowning a wider scope for voyeuristic psychoanalytical enquiry into madness as sexual and/or social deviance (inherited critically and achieved cinematically). Finally, the most radical departure both from the playscript and from previous stage/film productions this article focuses on is the work non-speaking Ophelia does from her first entrance, by examining how the three productions use this body at disposal and don't 'dispose' of it in Act Five - as indeed, there are no exit stage direction for 'the corpse of Ophelia' - and on what issues such choices might raise.

\section{Handling the body}

Listed in the Dramatis Personae as 'daughter to Polonius', Ophelia 'enters' the play in I.3 in 'a room in Polonius' house' as 'sister' to Laertes. Directors Vlad Mugur in 2001, Radu Alexandru Nica in 2008, and Jan Klata in 2014 re-wrote her entrance in an elaborate choreography. In Mugur's production, all actors were summoned into the play by the three customary gongs at the beginning of the performance: they left the auditorium, climbed onto the stage and literally took up their parts (left at random on chairs) in what looked like a cold reading. The production's first tableau offered four men and three women symmetrically positioned behind a row of three tables: stage right, a young fair Ophelia was sided by two strong young men, Laertes and Bernardo; centre stage, an elderly woman - Hecuba - sat on her own; stage left, a middle-aged woman - Gertrude - was flanked by two men, Claudius and Polonius.

Despite the actors' nondescript costumes and the silence they all kept throughout the abridged I.1 and II.2, two women’s performances stood out. They wore their similarly bleached blonde hair 'with a difference': the younger was visibly uncomfortable and belittled by her beefy looking brother, the other was more than comfortable in male company and generous in her gestural support of the visibly young(er) King Claudius. But Ophelia's first assumed entrance was a site of yet more telling tales. Shakespeare's I.3 in Mugur's production began in complete silence with Ophelia - a punk-goth-ed up Degas ballerina bizarrely whiling away time by playing golf. 
Figure 1. Ophelia (Luisa Cocora) in Vlad Mugur's Hamlet (National Theatre, Cluj, 2001). Courtesy of Luiza Cocora.

Her costume and performance were mapping out conflicting stories: the white ballerina tutu constrained into the black bodice summoned up childhood and sexuality, the white ballet leggings with black Doctor Martens made her the live dispute between "good girl" and "grrrl power”. The costume both infantilised and idealised the actor's body on display: it was a site of conflicting cultural metaphors and a disturbing sight of objectification, albeit in conflicting conventions (not just in terms of period, but also of medium - dance). ${ }^{8}$

Similar conflicts were signalled by Ophelia's entrance in Klata's production: having crossed half of the stage, she settled centre stage, and with meticulous gestures put on and tied up her pointe, arranged her leg warmers then proceeded, not without some reluctance, to the ballet barres (stage left) only to break into a free-style dance to a disco tune. Polonius's entrance curtailed her joy and freedom in more than the scripted way: in this production, he doubled as a tough ballet instructor who changed Ophelia's tape upon arrival and ensured she immediately returned to the strict ballet routine under his instructions.

Figure 2. Ophelia (Xenia Snagowski) practising under the strict eye of her ballet instructor, Polonius (Jürgen Hartmann) in Jan Klata’s Hamlet (Schauspielhaus, Bochum 2013, Gdansk 2014). (C) Greg Goodale / Greg Veit Photography.

The golf game (another set of strict rules) in Mugur's production was read by audiences first as masculine then, and perhaps more importantly, as foreign. This was the new language Ophelia spoke and the audience had to learn. Her actions, reflected in a mirror positioned deep stage (left), told yet another story. Allegorically, her game of golf anticipated the way in which she would be pushed from pillar to post by Laertes, Polonius, Hamlet, and Claudius, much like a golf ball. Metatheatrically, it illustrated the director's method of moving from one situation to the next during I.5: Ophelia arranged the balls so that each time she hit one, it stopped in the exact spot that each of the male characters had occupied earlier. Was Ophelia toying with her constraints or was she working out her priorities were questions this Hamlet posed directly. 
In Mugur's production, Ophelia was choreographing Hamlet the play, albeit through a sophisticated game of golf. Her story was one of the three dumbshows that the director scripted into Hamlet; the other two were the Ghost's re-enactment of his poisoning and Hamlet's silence(ing) during ‘To be or not to be' soliloquy. One effect of the dumbshows was to increase the pace of the performance. The other was to render any following speech and action as acts of violence against the respective silent (silenced?) protagonist: the Ghost itself would be present at the re-enactment of its poisoning during the play-within-the-play; Ophelia would be deprived of speech in the closet scene (played onstage as a dumbshow and commented on by Polonius who appropriated Ophelia's lines). Later, Ophelia would be deprived of action by Polonius (who manhandled her like a puppet to 'look natural' for the nunnery scene), then by Hamlet (in aggressive foreplay and lovemaking, only to be discarded by him), and, finally, she would be raped by Claudius, aroused by the nunnery scene he had just watched. Klata's 'nunnery scene' was equally violent and ended with Ophelia lying on the stage among the scattered books - another discarded object. This was the state in which Ophelia delivered the speech generally regarded as 'her only unmediated articulation of subjectivity'. ${ }^{9}$

From her first entrance in Nica’s production in Sibiu (2008), Ophelia (Ophelia Popii), too, was 'out of her text' and 'out of her part' - as Olivia and Viola would put it. She entered the CCTV-ed space not to Laeters, but to Hamlet, the Prince whom Horatio was busy convincing to take up the Ghost's task of revenge. Like Claudius, Polonius, Laertes, and Gertrude, who as soon as they made their entrances took the mic (stage fore) and declared their part in the story, Ophelia too was a contestant in the Hamlet play. She captioned her story: 'Hamlet and Ophelia. A Love Story by William Shakespeare', and followed it up with a song and dance number whose lyrics 'Doubt thou the stars are fire. / Doubt that the sun doth move. / Doubt truth to be a liar. / But never doubt I love’ (II.2.115-8) she delivered in English.

Like Luiza Cocora's performance in Mugur's production and Xenia Snagowski's in Klata’s, Ophelia Popii’s performance in Nica’s worked in multiple codes. Her polka-dotted red velvet mini-dress with layered underskirts and her 'fair' hair were not childish but versatile.

Figure 3. The 'nunnery scene': Hamlet (Ciprian Scurtea) and Ophelia (Ofelia Popii) in Radu Alexandru Nica’s Hamlet, (Sibiu, 2008). Courtesy of 'Radu Stanca' Theatre, Sibiu. 
Her out-of-a-bottle blonde hair spilling out of two red elastic bands matching her red boots, the low neck dress - with one sleeve bursting at the shoulder and held together by safety pins, and the other made of beige lace to match her stockings (forever dropping) - signalled that this Ophelia was not playing but playing with "dumb blonde" and "girl power" objectifications. She was performing and clowning both deliberately: for Hamlet, she put on an X-Factor - pole dancing number, playing both pretty and erotic; for her father, later, she pulled her underskirt down to her calf (level of 'propriety') but only half listened to his words and gave her replies distractedly because, behind Polonius's back, she was blowing kisses to Hamlet who, she knew full well, could see her on one of the CCTV cameras in this Elsinore under surveillance. While Luiza Cocora's Ophelia, who played hide-and-seek with and got a piggy-back ride from her brother, Laertes, remained oblivious to both her sex appeal and Hamlet's interest in her, Ofelia Popii's Ophelia responded to Laertes's and Polonius's double standards with some of her own. Laertes's first entrance interrupted Ophelia and Hamlet's dance; their obvious intimacy prompted his warning; he returned twice to complete his advice and to physically drag Ophelia out of Hamlet's arms. In a similar manner, while Polonius poured his advice ('to thine self be true') on his son, Ophelia was not only present on stage, occupying the counter story in this production of Hamlet, but also mocked his double standards: she and the Prince, cuddled up in two chairs (stage depth), dubbed Polonius's words loudly and burst the soap bubbles Horatio was busy blowing over them. Likewise, Xenia Snagowski's Ophelia, was 'keeping her [own] council'. Considering that Polonius found her half undressed, ankles and wrists duck-taped to the top ballet barres in her room (during the aggressive foreplay the audience had just witnessed), her speech 'as I was sewing in my closet' (in II.1) was, blatantly, a cover up story.

\section{'T’have seen what I have seen, see what I see!’ (III.1.162)}

In most productions of Hamlet, Ophelia breaks in the 'nunnery scene', yet as the productions discussed in this article suggest, she does so at different points in the scene. Overtly sexualised, in all four productions, the choreography of the 'nunnery scene' disambiguated Hamlet and Ophelia's relationship and in doing so did more than objectify Ophelia and satisfy the voyeuristic spectators (Claudius and Polonius, as much as the audience). This objectification, however, did not deny Ophelia 'her subjectivity in the process' - as it is the case, Rutter argues, in Branagh's 1996 film version. ${ }^{10}$ In Mugur's 2000 production, this - for Hamlet at least - began as the love consummation scene for the two protagonists, which turned abusive only when Hamlet suspected they were watched, and realised he himself is 
thus objectified in a different story (namely, Claudius and Polonius's). In Nica’s 2008 and Klata's 2013/2014 productions, Hamlet and Ophelia's love story had been in close competition with the revenge task overtly and from the beginning, and only lost terrain when Hamlet was finally recruited to the revenge plot.

In this sense, both Hamlet and Ophelia were objectified in projects neither of their making nor of their choosing: Hamlet in his father's Ghost's project, Ophelia in Polonius and Claudius's. It is with this realisation then that the love story as a possibility fell apart: Ophelia who came to the scene with 'love remembrances' to return, was forced to remain in possession of them. In Nica's production, these tokens and Hamlet's lines 'I loved thee once' and 'I loved you not' would be remembered in everything Ophelia did thereafter: grotesquely, at the end of the nunnery scene (3.1) when Ophelia, staring blankly at the TV screen (stage left) which played on a loop, a merry-go-round clip, in black-and-white, complete with musical box soundtrack, lulled the 'Never doubt I love' of her first song. The line returned in IV.5, first as a screeched refrain linking her 'mad songs' and later when handing out sleeping pills (this production's flowers?) slipped to her earlier by Claudius. The lines recurred one last time, when the ceiling projection from the 'nunnery scene' was replayed with a difference: the green floral pattern invaded by red stems became blurred by Hamlet's letters whose blue handwriting dissolved to give it a watery quality, anticipating her drowning. In Nica's production Ophelia remained on stage to hear the news that Hamlet returned and to see Laertes enter.

As in any Hamlet production, Ophelia's transformation was registered at the level of costume, too. In 2000, Ophelia - abused and discarded by Polonius, Hamlet and Claudius, her tutu torn to reveal raw-pink underwear, black eye-liner running down her face, 'hair in disarray' and 'knees knocking' (sinisterly reminiscent of Hamlet's ravished state when bursting into her closet earlier) - crawled stage left to deliver her soliloquy, which although truncated to six lines (three about her and three about Hamlet) registered that she had seen his madness and foretold her own collapse into it - 'of ladies most dejected and wretched' (III.1.156).

But Mugur's production did not go for 'decorative madness' ${ }^{11}$ Ophelia's costume changed to a black tube dress whose extra-long sleeves were more reminiscent of a straitjacket than a fashion statement. In both 'mad' scenes she entered abruptly and unannounced. First, she 
interrupted the King and Queen, following Hamlet's curt dispatch to England, demanded their attention and held it throughout her scene; her 'pray you, mark' (IV.5.28) in this production was closer to a military order, which translated in Romanian literally as 'Attention, please'. Ophelia's exit was equally disturbing in its ambiguity: the 'coach' (IV.5.72), in this production a wheelbarrow, rendered her body both as disposable rubble and construction material.

Figure 4. Ophelia’s ‘coach’ in Vlad Mugur’s Hamlet (National Theatre, Cluj, 2001). Courtesy of Luiza Cocora.

On her second coming, Ophelia descended from the heavens (a fallen angel abseiling on ropes which had buckets tied to their ends) and interrupted Laertes, Claudius, and Gertrude’s council to give her tokens of remembrance. Her 'pansies', 'daisies', and 'violets' (IV.5.17785) were the clods with which Laertes's army threatened to overthrow Claudius's reign earlier - suggesting that this Ophelia had acted on the words 'My brother shall know of it' (IV.5.71, a line this production cut). In Klata's production, too, Ophelia's madness was inscribed on her costume and make-up as much as in her behaviour. When she entered 'distracted', Ophelia wore an oversized white T-shirt and laddered black tights, red lipstick smeared around her mouth; on her second entrance, however, as a half-dressed ballerina, Ophelia did not sing her scripted part but spoke the lines of another Ophelia - Heine Müller's - a disconcerting textual intervention which both anticipated and commented on her own drowning.

Figure 5. Right: 'I am Ophelia. The one the river didn't keep. The woman dangling from the rope. The woman with her arteries cut open. The woman with the overdose. SNOW ON HER LIPS (...).’ (c) Greg Goodale /Greg Veit Photography.

\section{'There is a willow grows askant a brook' (IV.7.166)}

But in Mugur's 2000 production Ophelia suspended on ropes and the buckets were not the only choreographed references to her drowning. The very problematics of her drowning returned in Gertrude's speech as the Queen herself struggled to make sense of the events, and later, with clear visual impact, in the Clowns' debate on whether she 'drowned herself wittingly' or it was a case of 'se offendendo' (V.1.9-10), a debate this production played out: the Clowns lifted a trap in the floor to revealed the 'brook', full of white lime paste (whose composition was carefully timed to solidify by the end of each performance). The hole 
became Ophelia's grave only after it was emptied of the other stories brought out as disinterred remains by the Gravediggers.

Nica, on the other hand, positioned his 2008 production against two interpretative directions: on the one hand, it pitched against psychoanalytical readings of the play epitomised by Olivier's 1948 film, which this Hamlet cited frequently and which, the director argued, 'plagued' twentieth-century Hamlets, and on the other, against what he termed the 'rhetoriccentred tradition of performing Hamlet in Romania'. ${ }^{12}$ Taking conscious distance from both, his production 'ventured, instead, a cinematic montage' that 'engage[d] in polemical dialogue' with both logocentric and 'cinema' productions. The choreography of the 'drowning scene' which was performed three times - in the clip from Olivier's film projected on one of the TV screens on the stage; in Gertrude's speech; in Ophelia's enacting - rendered this dialogic relation emulative, reiterative, and negotiable, in the spirit of drama-therapy convention this production put forward. This production's Danish Prince mimed Olivier's speech (simultaneously projected on the TV screen stage left), then gun-shot it to make room for his own 'To be or not to be'; the result was that Scurtea's Hamlet literally muted Olivier's, cutting off the sound of the film but not erasing the image: the projection let Ophelia linger, with her 'nymph'-like body floating in the depth of Olivier's 1948 set of dark corridors, framed her in then out of view, finally cutting to a shot of Olivier's naturalist 'brook and wild flowers' bed for drowned Ophelia. This live cross-referencing of Ophelia's drowning with its cinematic and visual heritage worked at the level of iconography, textual intervention, and spectating. Gertrude delivered the news at the mic forestage, while Claudius and Laertes continued to choreograph the duel unperturbed, stage-right; stage-depth, Ophelia performed the scene, up-side-down, drowning into the water projected on the ceiling screen that boxed this production's set.

Though simultaneously delivered, the three actions were taken on board by the spectator's eye individually (as they had to prioritise the stories in a manner akin to computer editing) and relationally (as cause and effect), registering the 'drowning' as speech, as action, and finally, as viewing, when the whole scene uncannily resembled a news report with live footage, ending in this production, where Shakespeare's scene started: 'Your sister's drowned, Laertes.' (IV.7.164) This was another example of the production's employment of close up and long shot, which it used productively to juxtapose Gertrude and Ophelia, as well as their respective stories. The two female characters reversed performances after their 
respective closet scenes: the more exposed and sexualised Ophelia's body and performance, the more composed and restraining Gertrude's. So did their costumes: the Queen's outfits changed from provocative red and black minis to full length black, while Ophelia's became more revealing - the polka-dotted red dress and red boots were shed for a black bodice and suspenders, accessorised with a full length lace gown and boots in matching black.

\section{'Maimèd [funeral] rites' (V.1.215)}

'Drowned' Ophelia was a reality difficult to handle in Nica's 2008 production: first by Laertes, who never spoke his scripted lines (IV.7.185-91) but struggled with the weight of Ophelia's dead body, a rag doll in his arms, yet as disobedient in his hands as she was in the advice scene (in II.2). Eventually balancing her dead body, he placed it on chairs facing each other - creating an impromptu coffin - before handing it over to the two morticians (this production's version of the Gravediggers). Not only was Ophelia-the-body but also Opheliathe-icon mishandled in this production: the two morticians combed her hair and tried to restrain it with a black hair band (a futile attempt given that her head was hanging down), and touched up her makeup with heavy strokes and strong colours for her last public entrance. The blue lipstick and eye-shadow were no fashion statement but stage economy: they actually constructed 'drowned' Ophelia. Throughout the scene - complete with dialogue about death, the law, propriety - Ophelia's head, hanging limp, facing the audience up-side-down, signalled the separation between mind and body that governed the story she wanted remembered, then subverted this possibility as the image was at once reminiscent of a magician's trick of cutting the boxed female body. This was another box that could not contain Ophelia's body - like her child-dress bursting at the seams she wore earlier. Hamlet himself felt the weight of this dead body when finally claiming it in the funeral scene: his ' $I$ lov'd Ophelia' speech was another dance macabre in which he staggered across the stage with 'fair Ophelia' in his arms, then collapsed on a chair holding her on his lap (an oversized child in a strangely inverted pieta), and finally lay her to rest (on a chair stage depth). From there dead Ophelia watched "the rubbish" of V.2.

Mugur, too, ad-lib-ed Ophelia's last entrance in his 2000 production: Ophelia, in her black tube dress stretching over her bloated (pregnant?) body was walked in by the guards and placed vertically in the grave; as Laertes and Hamlet 'leap[t] into the grave', her body was once again disputed by her brother and her lover, an action which turned her into another dead tossed around (much like Yorick’s skull earlier). But the 'maimèd rites' did not finish 
there in Mugur's 2000 production: on Claudius's promise of 'a living monument', Gravedigger 1 walked Ophelia (covered in white lime paste) out of the grave, over the stage, through the audience, and out of the auditorium, clearing the scene for Hamlet's story of revenge.

\section{'A living monument' (V.1.283)}

Textually, Ophelia as a body and her story are erased at the end of V.1. Never given the 'living monument' Claudius promises, she is displaced by the play's need for heroic closure, which puts, once again, in fierce competition the dead body and the body-politic. It did so when the Ghost came to trouble Claudius's reign; it does it again when Ophelia's body is erased by state matters. In the process, Hamlet's funeral is 'maimèd', too, and his story hijacked: it is not 'flights of angels' that 'sing him 'to [his] rest!' but, at Fortinbras's command, 'soldiers’ music and the rites of war | [that] Speak loudly for him.' (V.1.393-4)

It is the play's ending where the productions examined in this article depart most acutely from the playscript and from one another. In Mugur's 2001 Hamlet, once the scripted Act Five concluded with Fortinbras, a golden boy aged 7, who having appropriated Horatio's lines promised to uncover 'how these things came about' (V.2.374), the spectators walked out of the auditorium into the foyer only to discover Ophelia - a sinister 'living monument', the lime paste around her ankles threatening to set her into concrete. In Klata's 2014 production, Ophelia never entered as a 'corpse': she was replaced by an oversized pot of ashes Laertes had to inter in the oversized grave carefully erected by the cast from the books scattered on the stage, and instantly destroyed in Hamlet and Laertes’s fight.

Figure 6. Left: Rosencrantz, Gertrude, Laertes with Ophelia's ashes, Claudius, Horatio, and Guildenstern in Klata’s Hamlet. Gdansk 2014 (c) Greg Goodale/ Greg Veit Photography.

Rosencrantz and Guildenstern's subsequent attempt to give her a 'lasting monument' was equally futile: their project was repeatedly set up to fail, to their increasing frustration and the audience's laughter, as the book tower collapsed because they always started with the smaller books as their foundation. Ophelia, however, was granted a monument of a different kind: in an uncanny take over, Horatio - in a white tutu and black pointes - became her 'living monument' and continued to tell her story during the final act. 
Figure 7. Right: In the background, Rosencrantz and Guildenstern construct Ophelia's precarious 'living monument' in Klata's Hamlet. Gdansk 2014 (C) Greg Goodale/ Greg Veit Photography.

In Nica's 2008 production, while the dead bodies (Ophelia's, Gertrude's, Laertes's, Claudius's, and Hamlet's) were still visible on stage, the projection on the screen ceiling showing Horatio and the two Gravediggers 'pil[ing] dust upon the quick and dead' (V.1.247) threatened to bury all stories in a communal grave - a site of erasure but also, as in Shakespeare’s Gravediggers’ scene earlier, one ripe for disinterring and remembering.

\section{'Exeunt'}

Yet little of these productions' brave stage work of handling Ophelia, work which overtly tells other stories, is remembered or directly acknowledged. The promotion material for the productions discussed barely notices it; when doing so, it is not in the directors' or the other contributors' notes, but buried among the customary photographic tokens. Even less is visible in the reviews, which either don't seem to notice these aspects or choose to gloss over them in favour of the standard lead-man's story at best contrasted with previous stage versions. A study of the actors' views on the parts of Ophelia they were directed to perform remains a task for the future, and the question: what is the space this live cultural negotiation between theatre practice and academic debate does occupy when it comes to Ophelia performed? is yet to be asked. My concern is that in both cases, Ophelia (the part, body, agency, story) is in danger of being lost to Parsons' fallacy of normative determinism, that is, seeing the normative order as 'constitutive rather than regulative, of the self', 'social actors (qua role bearers) as a reflex of the social system' and 'meaning as a faithful imprint of the cultural pattern. ${ }^{, 13}$ While perhaps guilty of its own (mis)handlings, my attempt to recuperate stage Ophelias hopes to have done some of the catching up work theatre reviewing needs to undertake in order to deliver the interpretative 'living monument' to Ophelia that theatre practice has been busy building in recent European productions of Hamlet.

\footnotetext{
${ }^{1}$ All quotations from the play are from T.J.B. Spencer's edition of Hamlet. New Penguin Shakespeare (London: Penguin, 2005) and will be referenced parenthetically in the text.

2 Carol Chillington Rutter, Enter the Body: Women and Representation on Shakespeare's Stage (London: Routledge, 2001), p.29.

3 The eclectic range of accessories includes, among others: Ophelia bespoke hosiery, Ophelia suicide shoes (complete with detail from Alexandre Cabanel's 1883 painting), Sadistic Ophelia Skate Deck, an Ophelia Corrective Academy Hoodie for Recalcitrant Young Ladies, and an Ophelia’s Gaze: Bruised Avatar Skins, in
} 
which a black left eye Ophelia invites potential customers to debate if sporting it is stylish or sexist.

${ }^{4}$ Among recent projects that take up the versatility of this character and its afterlives, several are of particular interest: Five Truths (video installation by Katie Mitchell, Victoria \& Albert Museum, London, 2011), The Afterlife of Ophelia (Basingstoke: Palgrave Macmillan, 2012), Ophelias. Iconography of Madness (by Łódź Art Museum and Wroclaw Contemporary Museum, Poland, presented at the Gdansk Shakespeare Festival, 2013), Claiming the body: the Ophelia myth in the GDR (Ruth Owen's article for the Germanic Review 82.3 (2007): 251-267), and Kristin and Davy McGuire Ophelia's Ghost as part of the exhibition Shakespeare in Art: Tempests, Tyrants and Tragedies, at Compton Verney Art and Gallery Park, UK, during the summer of 2016.

${ }^{5}$ Rutter, p.29.

${ }^{6}$ My statistics are drawn from the New Penguin Shakespeare edition of Hamlet, edited by T.J. B. Spencer (2005). Statistics on Ophelia's spoken input are similar between editions (Q1, Q2 and F) and editors (for the purpose of this article I have contrasted Spencer's edition with Philip Edwards's New Cambridge Shakespeare - 2003, Jonathan Bate and Eric Rasmussen's RSC William Shakespeare Complete Works - 2007, Ann Thompson and Neil Taylor's Arden Shakespeare Hamlet (The Second Quarto 1604-5) - 2006 and Hamlet: The Texts of 1603 and 1623 - 2007, and The Norton Shakespeare edited by Stephen Greenblatt et al - 2015.

${ }^{7}$ This is not a strategy unique to the case of Ophelia, but one which Shakespeare employs when dealing with other "disruptive" female characters - see, for example, Marcus's struggle to comprehend the sight of mutilated Lavinia in Titus Andronicus or the Gentlewoman's report - to the Doctor - on Lady Macbeth's sleepwalking in Macbeth.

${ }^{8}$ Ophelia's part has been associated with dance before in other productions of Hamlet. One Romanian example is Ioan Sapdaru's 1998 production for the 'Mihai Eminescu' Theatre, Botoşani, in which the closet scene, the nunnery scene and the drowning scene were all choreographed as ballet in slow motion (in a combination of strobe and red light). More recently, Ophelia told most of her story through dance in Tiger Lilies and Copenhagen Republique Theatre's ‘opera grotesque’ Hamlet (which I saw at the Gdansk Shakespeare Festival in 2015).

${ }^{9}$ Rutter, p.30.

${ }^{10}$ Rutter, p.47.

${ }^{11}$ Rutter, p.38.

${ }^{12}$ Hamlet - Production Programme Notes, Sibiu, 2008.

13 José Guilherme Merquior, The Veil and the Mask: Essays on Culture and Ideology (London: Routledge \& Kegan Paul Ltd., 1979), p.55. 